\title{
Chromosome- and plasmid-mediated gentamicin resistance in Staphylococcus aureus encoded by Tn4001
}

\author{
M. T. GILLESPIE," B. R. LYON,† L. J. MESSEROTTI and R. A. SKURRAY
}

Department of Microbiology, Monash University, Clayton, Victoria 3168, Australia

\begin{abstract}
Summary. DNA sequences corresponding to the $4 \cdot 7-\mathrm{kb}$ gentamicin, tobramycin and kanamycin resistance $\left(\mathrm{Gm}^{\mathrm{r}} \mathrm{Tm}^{\mathrm{r}} \mathrm{Km}^{\mathrm{r}}\right)$ transposon $\mathrm{Tn} 4001$ have been detected on a series of nine structurally-related plasmids that mediate this phenotype in Australian isolates of Staphylococcus aureus. Tn 4001 sequences have also been demonstrated on the chromosomes of $\mathrm{Gm}^{\mathrm{r}} \mathrm{Tm}^{\mathrm{r}} \mathrm{Km}^{\mathrm{r}}$ isolates that do not possess these plasmids, and the exhibited diversity of chromosomal sites occupied by this element implies that Tn4001 has transposed to the chromosome on numerous occasions in vivo. These results suggest that the rapid emergence of nosocomial $\mathrm{Gm}^{\mathrm{r}} \mathrm{Tm}^{\mathrm{r}} \mathrm{Km}^{\mathrm{r}} S$. aureus in the early 1980s may have been the result of the transposition of Tn 4001 from a chromosomal site to a readily disseminated plasmid.
\end{abstract}

\section{Introduction}

In nosocomial isolates of Staphylococcus aureus, resistance to gentamicin $\left(\mathrm{Gm}^{\mathrm{r}}\right)$ and the related aminoglycosides tobramycin $\left(\mathrm{Tm}^{\mathrm{r}}\right)$ and kanamycin $\left(\mathrm{Km}^{\mathrm{r}}\right)$ has often been correlated with the presence of plasmids (Jaffe et al., 1982; Gray et al., 1983; Lyor et al., 1983; Naidoo et al., 1983; Townsend et al., 1984b). These plasmids may encode additional functions including resistance to acriflavine $\left(\mathrm{Ac}^{\mathrm{r}}\right)$, ethidium bromide $\left(\mathrm{Eb}^{\mathrm{r}}\right)$, quaternary ammonium compounds $\left(\mathrm{Qa}^{\mathrm{r}}\right)$, trimethoprim $\left(\mathrm{Tp}^{\mathrm{r}}\right)$ and penicillin $\left(\mathrm{Pc}^{\mathrm{r}}\right)$ and some are also capable of mediating their own transfer (McDonnell et al., 1983; Goering et al., 1985; Archer et al., 1986; Gillespie and Skurray, 1986). In multiresistant strains of $S$. aureus from Australia, the 28.4-kilobase pair (kb) $\mathrm{Gm}^{\mathrm{r}}-$ $\mathrm{Tm}^{\mathrm{r}} \mathrm{Km}^{\mathrm{r}} \mathrm{Ac}^{\mathrm{r}} \mathrm{Eb}^{\mathrm{r}} \mathrm{Qa}^{\mathrm{r}} \mathrm{Tp}^{\mathrm{r}}$ plasmid pSK1 (Lyon et al., $1984 a, 1986$ ) was shown to carry a $4 \cdot 7-\mathrm{kb}$ transposon, Tn4001, that encodes resistance to the aminoglycosides (Lyon et al., 1984b). Analysis of plasmids in North American strains of $S$. aureus revealed that $\mathrm{Gm}^{\mathrm{r}} \mathrm{Tm}^{\mathrm{r}} \mathrm{Km}^{\mathrm{r}}$ was encoded by a transposonlike element that possessed substantial homology with Tn4001 (Lyon et al., 1987), thereby suggesting

Received 17 Sep. 1986; accepted 15 Oct. 1986.

- Present address: Research Centre for Cancer and Transplantation, Department of Pathology, University of Melbourne, Parkville, Victoria 3052, Australia.

† Present address: Department of Genetics, Monash University, Clayton, Victoria 3168, Australia.

$\ddagger$ Correspondence and offprint requests should be sent to Dr R. A. Skurray. that $\mathrm{Gm}^{\mathrm{r}} \mathrm{Tm}^{\mathrm{r}} \mathrm{Km}^{\mathrm{r}}$ plasmids detected worldwide might carry elements analogous to Tn 4001 .

In several $S$. aureus isolates from Europe, $\mathrm{Gm}^{\mathrm{r}} \mathrm{Tm}^{\mathrm{r}} \mathrm{Km}^{\mathrm{r}}$ could not be linked to a plasmid locus (El Solh et al., 1981; Kayser et al., 1981; Witte and Dünnhaupt, 1984; Coleman et al., 1985), and in one instance the $\mathrm{Gm}^{\mathrm{r}} \mathrm{Tm}^{\mathrm{r}} \mathrm{Km}^{\mathrm{r}}$ determinant was cloned from a chromosomal site (El Solh et al., 1986). Some Australian strains also exhibit chromosomal $\mathrm{Gm}^{\mathrm{r}} \mathrm{Tm}^{\mathrm{r}} \mathrm{Km}^{\mathrm{r}}$ and similarities amongst the aminoglycoside resistance levels of these strains and those bearing pSK 1 (Lyon et al., 1983; Gillespie et al., 1984, 1985) suggest that the $\mathrm{Gm}^{\mathrm{r}} \mathrm{Tm}^{\mathrm{r}} \mathrm{Km}^{\mathrm{r}}$ determinants may be identical. Evidence that Tn4001 readily transposes from plasmids to the staphylococcal chromosome in vitro (Lyon et al., $1984 b$; G. Mahairas, B. Lyon, R. Skurray and P. Pattee, unpublished observation) implies that this element may be similarly active in vivo. In this paper, we examine the location of transposonTn 4001 on plasmids and chromosomes of $\mathrm{Gm}^{\mathrm{r}}$ $\mathrm{Tm}^{\mathrm{r}} \mathrm{Km}^{\mathrm{r}}$ strains of $S$. aureus from Australian hospitals.

\section{Materials and methods}

\section{Bacterial strains and plasmids}

Clinical isolates of $S$. aureus were obtained from Australian hospitals during the period 1976-1982 and many have undergone preliminary analysis (Lyon et al., 1983, 1984a; Gillespie et al., 1984, 1985, 1986). The size 
and resistance patterns of the plasmids detected in these strains are listed in table I. The relevant characteristics of $S$. aureus isolates employed in hybridisation studies are presented in table II.

\section{General methods}

Standard culture media and methods for the determination of antimicrobial susceptibilities and the transfer of plasmids by mixed culture have been described before (Lyon et al., 1983, 1987; Gillespie et al., 1985).

\section{$D N A$ isolation, restriction analysis and $D N A-D N A$ hybridisation}

Purified plasmid DNA was isolated as previously described (Lyon et al., 1983) and whole-cell DNA was prepared by a rapid DNA-isolation technique (Lyon $\boldsymbol{e t}$ al., 1984a). Digestion with the restriction endonucleases EcoRI, Eco RV, HaeIII, HincII, HindIII and TaqI (New England Biolabs), agarose gel electrophoresis, the estimation of DNA-fragment sizes, the isolation of probe DNA and DNA-DNA hybridisation were performed as reported by Lyon et al. $(1983,1987)$.

\section{Results}

\section{Detection of Tn4001 on Australian $\mathrm{Gm}^{r} \mathrm{Tm}^{r} \mathrm{Km}^{r}$ plasmids}

Plasmid-DNA analysis of 280 strains of multiresistant $S$. aureus isolated from hospitals throughout Australia during 1980-1982 revealed that $>50 \%$ of the organisms carried a member of a family of closely related plasmids of which pSK 1 is the prototype (Lyon et al., 1983, 1984a). All but one of the pSK1-related plasmids encode $\mathrm{Ac}^{\mathrm{r}} \mathrm{Eb}^{\mathrm{r}} \mathrm{Qa}^{\mathrm{r}}$ and most mediate at least one other resistance phenotype which may include $\mathrm{Gm}^{\mathrm{r}} \mathrm{Tm}^{\mathrm{r}} \mathrm{Km}^{\mathrm{r}}, \mathrm{Tp}^{\mathrm{r}}$ or $\mathrm{Pc}^{\mathrm{r}}$ (table I). Restriction endonuclease analysis of these plasmids, such as the EcoRI and HindIII double digest presented in fig. 1A, demonstrated a high degree of similarity; the minor structural differences correlated with variations in plasmid phenotype.

Nine of the pSK 1-related plasmids (pSK1, pSK4, pSK8, pSK9, pSK11, pSK14, pSK 15, pSK 16 and pSK 17) mediate $\mathrm{Gm}^{\mathrm{r}} \mathrm{Tm}^{\mathrm{r}} \mathrm{Km}^{\mathrm{r}}$, and all were found to possess a characteristic doublet of HindIII fragments equivalent to the HindIII fragments D and $E(2.50$ and $2.45 \mathrm{~kb}$, respectively) of pSK 1 (fig. 1A, lanes b, c, e, f, g, h, i, j and k). The two $\mathrm{Gm}^{\mathrm{s}} \mathrm{Tm}^{\mathrm{s}} \mathrm{Km}^{\mathrm{s}}$ plasmids pSK 7 and pSK 18 possessed the 2.45-kb Hind III fragment E but lacked the 2.5kb Hind III fragment D (fig. 1A, lanes d and 1 ). These findings correspond with previous evidence that the $2 \cdot 5-\mathrm{kb}$ Hind III fragment D of pSK 1 maps symmetrically within the $4 \cdot 7-\mathrm{kb} \mathrm{Gm}^{\mathrm{r}} \mathrm{Tm}^{\mathrm{r}} \mathrm{Km}^{\mathrm{r}}$ transposon Tn4001 and results from the presence of Hind III sites in the $1.35-\mathrm{kb}$ inverted repeats of the element (Lyon et al., 1984b).

The presence of $\operatorname{Tn} 4001$ sequences in all of the $\mathrm{Gm}^{\mathrm{r}} \mathrm{Tm}^{\mathrm{r}} \mathrm{Km}^{\mathrm{r}}$ plasmids was confirmed by hybridisation with a $2 \cdot 5-\mathrm{kb} H$ ind III fragment derived from the recombinant plasmid pSK 310 which is equivalent to the Hind III fragment D of pSK1 (Lyon et al., 1987). All nine plasmids were shown to possess a $2 \cdot 5-\mathrm{kb}$ fragment that hybridised to the probe (fig. 1B, lanes b, c, e, f, g, h, i, j and k). Moreover, these $\mathrm{Gm}^{\mathrm{r}} \mathrm{Tm}^{\mathrm{r}} \mathrm{Km}^{\mathrm{r}}$ plasmids produced HaeIII fragments of $3.9 \mathrm{~kb}$ that possessed sequences homologous to the $2 \cdot 5-\mathrm{kb}$ Hind III fragment of pSK 310 (data not shown). This finding correlates with restrictionmapping data for Tn 4001 indicating the presence of symmetrical HaeIII sites, $3.9 \mathrm{~kb}$ apart, within the transposon (Lyon et al., 1987). However, the $\mathrm{Gm}^{\mathrm{s}} \mathrm{Tm}^{\mathrm{s}} \mathrm{Km}^{\mathrm{s}}$ plasmids, pSK7 and pSK 18 failed to hybridise with the probe (fig. $1 \mathrm{~B}$, lanes $\mathrm{d}$ and $\mathrm{l}$ ) or

Table I. S. aureus plasmids and their characteristics

\begin{tabular}{|c|c|c|c|}
\hline Plasmid & Phenotype* & Size $(k b)$ & Reference \\
\hline pSK1 & $\mathrm{Gm}^{r} \mathrm{Tm}^{\mathrm{r}} \mathrm{Km}^{\mathrm{r}} \mathrm{Ac}^{\mathrm{r}} \mathrm{Eb}^{\mathrm{r}} \mathrm{Qa} \mathrm{a}^{\mathrm{r}} \mathrm{T} \mathrm{p}^{\mathrm{r}}$ & $28 \cdot 4$ & Lyon et al. $(1984 \mathrm{a} ; 1986,1987)$ \\
\hline pSK4 & $\mathrm{Gm}^{r} \mathrm{~T} m^{r} \mathrm{Km}^{\mathrm{r}} A c^{r} E b^{r} Q a^{r} T p^{r} \mathrm{Pc}^{\mathrm{r}}$ & $35 \cdot 1$ & Lyon et al. (1984a) \\
\hline pSK 7 & $A c^{r} E b^{r} Q a^{r} T p^{r}$ & $23 \cdot 7$ & Lyon et al. $(1984 a, 1987)$ \\
\hline pSK 8 & $\mathrm{Gm}^{\mathrm{r}} \mathrm{Tm}^{\mathrm{r}} \mathrm{K} \mathrm{m}^{\mathrm{r}} \mathrm{Ac}^{\mathrm{r}} \mathrm{Eb}^{\mathrm{r}} \mathrm{Q} \mathrm{a}^{\mathrm{r}} \mathrm{T} \mathrm{p}^{\mathrm{r}} \mathrm{Pc} \mathrm{c}^{\mathrm{r}}$ & $35 \cdot 1$ & Lyon et al. (1983) \\
\hline pSK9 & $\mathrm{Gm}^{\mathrm{r}} \mathrm{Tm}^{\mathrm{r}} \mathrm{K} \mathrm{m}^{\mathrm{r}} \mathrm{Ac} \mathrm{c}^{\mathrm{r}} \mathrm{Eb}^{\mathrm{r}} \mathrm{Qa}^{\mathrm{r}}$ & $25 \cdot 7$ & Lyon et al. $(1984 a)$ \\
\hline pSK11 & $\mathrm{Gm}^{\mathrm{r}} \mathrm{T} \mathrm{m}^{\mathrm{r}} \mathrm{K} \mathrm{m}^{\mathrm{r}} \mathrm{Tp}^{\mathrm{r}} \mathrm{Pc}^{\mathrm{r}}$ & $41 \cdot 8$ & This paper \\
\hline pSK14 & $\mathrm{Gm}^{\mathrm{r}} \mathrm{T} \mathrm{m}^{\mathrm{r}} \mathrm{K} \mathrm{m}^{\mathrm{r}} A \mathrm{c}^{\mathrm{r}} \mathrm{Eb}^{\mathrm{T}} \mathrm{Qa}^{\mathrm{r}}$ & $24 \cdot 4$ & Lyon et al. $(1984 a)$ \\
\hline pSK 15 & 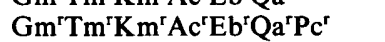 & $31 \cdot 1$ & Lyon et al. $(1984 a)$ \\
\hline pSK 16 & $\mathrm{Gm}^{\mathrm{r}} \mathrm{Tm}^{\mathrm{r}} \mathrm{Km}^{\mathrm{r}} \mathrm{Ac} \mathrm{c}^{\mathrm{r}} \mathrm{Eb}^{\mathrm{r}} \mathrm{Q} \mathrm{a}^{\mathrm{T}} \mathrm{T} \mathrm{p}^{\mathrm{r}} \mathrm{Pc} \mathrm{c}^{\mathrm{r}}$ & $35 \cdot 1$ & Lyon et al. $(1984 a)$ \\
\hline pSK 17 & 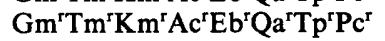 & $36 \cdot 4$ & This paper \\
\hline pSK 18 & $A c^{r} E b^{r} Q^{r}$ & $19 \cdot 7$ & Lyon et al. (1984b) \\
\hline
\end{tabular}

* Abbreviations as in text. 

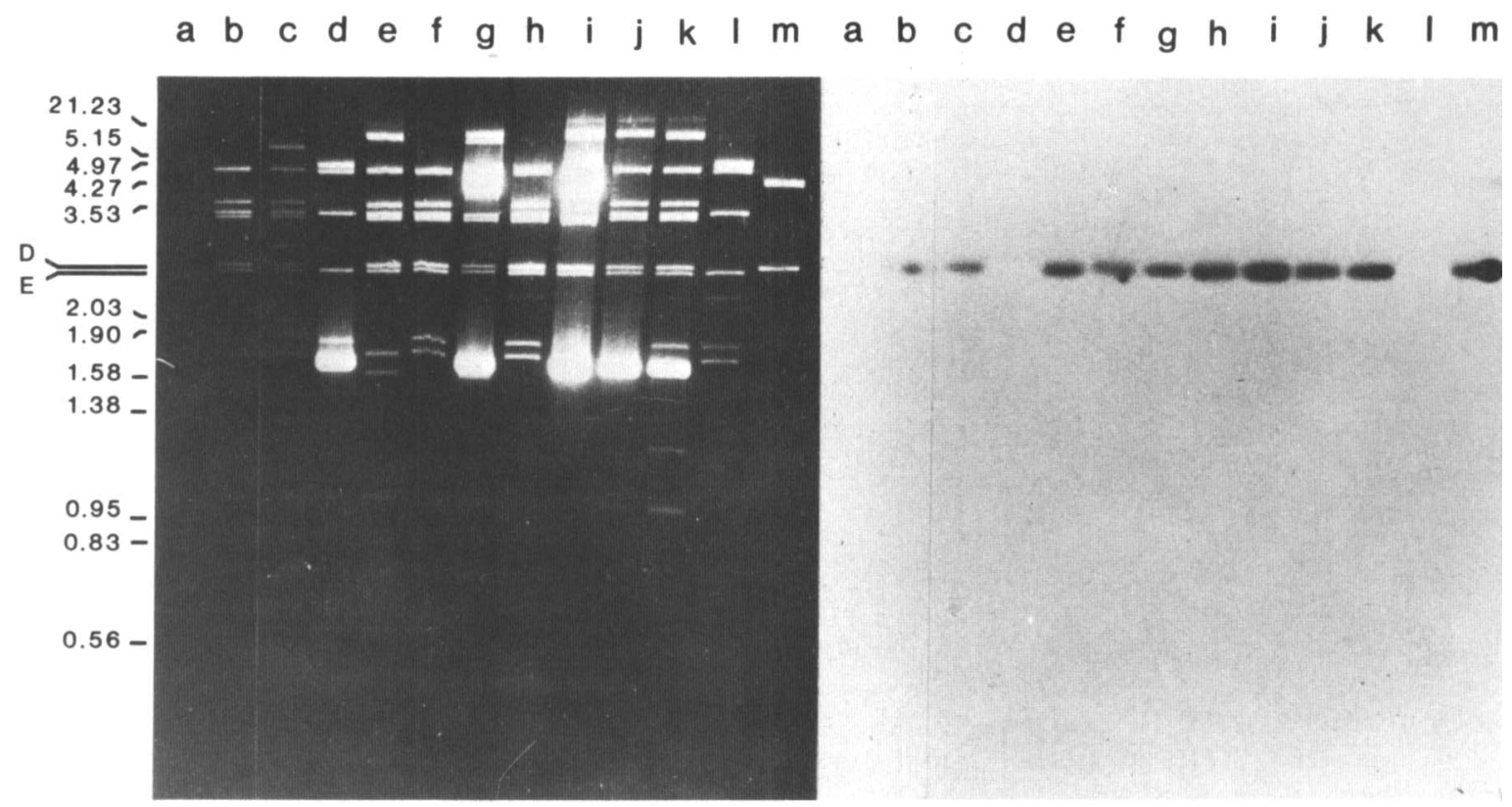

Fig. 1.A. Agarose gel $(2 \cdot 0 \%$ w/v) electrophoresis of purified $S$. aureus and Escherichia coli plasmid DNA cleaved with EcoRI and HindIII. The Hind III D and HindIII E fragments of pSK1 (lane b) are indicated by the letters D and E, respectively. The more intense bands in some lanes result from the presence of linear forms of plasmids pSK2 $(4.4 \mathrm{~kb})$ or pSK 3 ( $1.6 \mathrm{~kb})$ or both; these plasmids were often detected in clinical isolates (Lyon et al., 1984a). Lane a, lambda virus DNA cleaved with EcoRI and HindIII, fragment sizes (in kb) are shown at left; b, pSK1; c, pSK 4; d, pSK 7 and pSK3; e, pSK 8; f, pSK9; g, pSK 11, pSK2 and pSK3; h, pSK 14 ; i, pSK 15, pSK 2 and pSK 3 ; j, pSK 16 and pSK $3 ; \mathrm{k}$, pSK 17 and pSK3; 1, pSK18; m, pSK 310. (The lambda virus fragments were of less intensity than the plasmid fragments and do not reproduce well in the photograph).

B. DNA from gel A transferred to nitrocellulose and hybridised with a ${ }^{32} \mathrm{P}$ nick-translated probe consisting of the $2 \cdot 5-\mathrm{kb} H$ ind III fragment from pSK310.

produce a fragment of $3.9 \mathrm{~kb}$ when cleaved with HaeIII, thereby confirming the absence of Tn4001 in these two plasmids.

\section{Detection of Tn4001 sequences in strains exhibiting chromosomal $\mathrm{Gm}^{r} \mathrm{Tm}^{r} \mathrm{Km}^{r}$}

Plasmid-DNA analysis of more than $200 \mathrm{Gm}^{\mathrm{r}-}$ $\mathrm{Tm}^{\mathrm{r}} \mathrm{Km}^{\mathrm{r}} S$. aureus isolates failed to detect the presence of plasmids responsible for this phenotype in c. $25 \%$ and prompted the conclusion that the resistance determinant was chromosomal in these strains (Lyon et al., 1983, 1984a; Gillespie et al., $1984,1985)$. To test the hypothesis that this $\mathrm{Gm}^{\mathrm{r}} \mathrm{Tm}^{\mathrm{r}} \mathrm{Km}^{\mathrm{r}}$ determinant represented a chromosomal insertion of Tn4001, whole-cell DNA was isolated from selected clinical isolates of $S$. aureus (table II), cleaved with Hind III and hybridised with the 1-3-kb TaqI-HincII fragment of pSK310 which is specific for the central coding region of Tn 4001 ; this probe was used in preference to the 2.5-kb Hind III fragment because it lacks homology with the inverted repeat sequences of Tn 4001 , which have been found to occur independently at numerous sites in the chromosome (B. Lyon, $\mathbf{M}$. Gillespie and R. Skurray, unpublished observation). In digests of five of the $\mathrm{Gm}^{\mathrm{r}} \mathrm{Tm}^{\mathrm{r}} \mathrm{Km}^{\mathrm{r}}$ strains (SK1717, SK1734, SK1903, SK460 and SK457), a fragment equivalent to the $2 \cdot 5-\mathrm{kb}$ Hind III fragment from pSK310 (fig. 2A, lane a) was shown to be hybridised (fig. $2 A$, lanes $\mathrm{d}, \mathrm{e}, \mathrm{f}, \mathrm{g}$ and $\mathrm{h}$ ), whereas in the digest of the remaining $\mathrm{Gm}^{\mathrm{r}} \mathrm{Tm}^{\mathrm{r}} \mathrm{Km}^{\mathrm{r}}$ strain (SK 1774), a fragment of $3.8 \mathrm{~kb}$ hybridised with the probe (fig. 2A, lane c). As expected, digests of the $\mathrm{Gm}^{\mathrm{s}} \mathrm{Tm}^{\mathrm{s}} \mathrm{Km}^{\mathrm{s}}$ strains SK 1660 and SK 1589 did not hybridise with the probe (fig. 2A, lanes $\mathrm{b}$ and i).

A similar hybridisation experiment employing HaeIII-digested chromosomal DNA from these strains was conducted to provide more conclusive evidence for the presence of Tn4001 on the chromosome (data not shown). The 1.3-kb TaqIHincII fragment from pSK 310 hybridised with a 
Table II. Selected $S$. aureus strains and their characteristics

\begin{tabular}{|c|c|c|c|}
\hline Strain & $\begin{array}{l}\text { Year of } \\
\text { isolation }\end{array}$ & Phenotype* & Reference \\
\hline SK 1660 & 1976 & $\mathrm{Mc}^{r} \mathrm{Sm}^{\mathrm{r}} \mathrm{Tc}^{\mathrm{r}} \mathrm{Em}^{\mathrm{r}} \mathrm{Cd}^{\mathrm{r}} \mathrm{Hg}^{\mathrm{r}}$ & Gillespie et al. (1984) \\
\hline SK 1774 & 1977 & $\mathrm{Mc}^{r} \mathrm{Sm}^{\mathrm{r}} \mathrm{Tc}^{\mathrm{r}} \mathrm{Gm}^{\mathrm{T}} \mathrm{Tm}^{\mathrm{r}} \mathrm{Km}^{\mathrm{r}} \mathrm{Cd}^{\mathrm{r}} \mathrm{Hg}^{\mathrm{r}}$ & Gillespie et al. (1984) \\
\hline SK 1717 & 1977 & $\mathrm{Mc}^{r} S m^{r} T c^{r} E m^{r} G m^{r} T m^{r} K m^{r} N m^{r} A k^{r} C d^{r} H g^{r}$ & Gillespie et al. (1984) \\
\hline SK 1734 & 1978 & $\mathrm{Mc}^{r} S m^{r} \mathrm{~T} c^{r} E m^{r} G m^{r} T m^{r} K m^{r} N m^{r} C^{r} m^{r} d^{r} H^{r}$ & Gillespie et al. (1984) \\
\hline SK 1903 & 1978 & 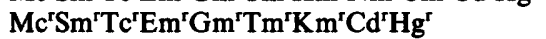 & Gillespie et al. (1984) \\
\hline SK460 & 1981 & 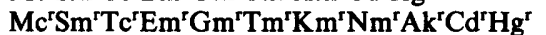 & Lyon et al. (1984a) \\
\hline SK457 & 1981 & 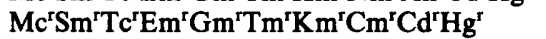 & Gillespie et al. (1984) \\
\hline SK1589 & 1981 & 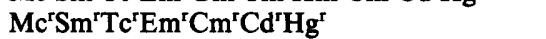 & Gillespie et al. (1986) \\
\hline
\end{tabular}

*Abbreviations as in text, with the addition of Mc, methicillin; Sm, streptomycin; Tc, tetracycline; Em, erythromycin; $\mathrm{Nm}$, neomycin; $\mathrm{Ak}$, amikacin; $\mathrm{Cm}$, chloramphenicol; $\mathrm{Cd}$, cadmium; $\mathrm{Hg}$, mercury.

3.9-kb HaeIII fragment in digests of strains SK1717, SK 1734, SK 1903, SK 460 and SK 457. This result is consistent with the carriage of $\operatorname{Tn} 4001$ on the chromosome in these strains. When the DNA from strain SK1774 was digested with HaeIII the probe hybridised with a fragment approximately $1.3 \mathrm{~kb}$ larger than the fragments detected in digests of the other $\mathrm{Gm}^{\mathrm{r}} \mathrm{Tm}^{\mathrm{r}} \mathrm{Km}^{\mathrm{r}}$ strains, a result which is compatible with the HindIII digest hybridisation with this strain (fig. $2 \mathrm{~A}$, lane c).

\section{Diversity of chromosomal sites occupied by Tn4001}

To establish whether the transposon has inserted at identical or different sites on the chromosomes of these strains, chromosomal DNA from the
A

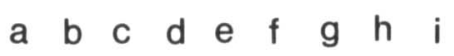

B

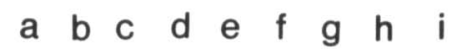

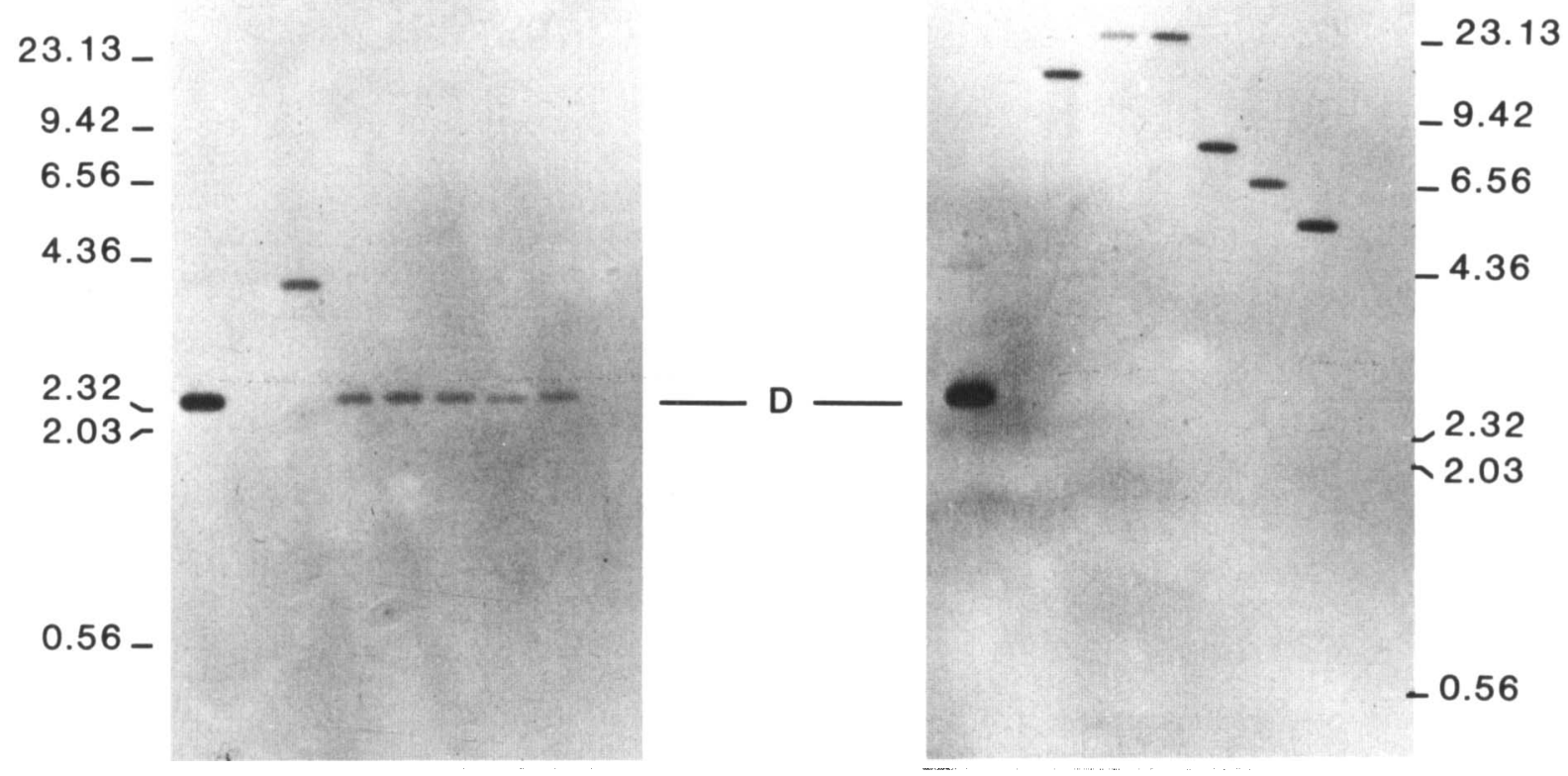

Fig. 2. Hybridisation analysis of clinical isolates of $S$. aureus demonstrating chromosomal $\mathrm{Gm}^{\mathrm{r}} \mathrm{Tm}^{\mathrm{r}} \mathrm{Km}^{\mathrm{r}}$. DNA extracted from selected strains by the rapid method was cleaved with HindIII (A) or EcoRV (B), electrophoresed on an agarose gel $0.8 \% \mathrm{w} / \mathrm{v}$, transferred to nitrocellulose, and hybridised with a ${ }^{32} \mathbf{P}$ nick-translated Tn4001-specific probe. Fragment sizes (in kb) of lambda virus DNA cleaved with HindIII are shown at left (A) and right (B). Lane a, pSK310 (in both A and B, pSK 310 was digested with HindIII; the 2.5-kb fragment equivalent to the Hind III D fragment of pSK1 is indicated by the letter D); b, SK 1660; c, SK1774; d, SK1717; e, SK1734; f, SK1903; g, SK460; h, SK457; i, SK1589. 
$S$. aureus clinical isolates was digested with the endonucleases $E c o$ RI and $E c o R V$, for which there are no sites within Tn4001. Hybridisation of the 1-3-kb TaqI-HincII probe with fragments of various sizes in EcoRI (data not shown) and EcoRV (fig. 2B) chromosomal digests indicated that Tn 4001 had inserted at various chromosomal sites. There were only two strains, SK 1717 and SK 1734 (fig. 2B, lanes $\mathrm{d}$ and $\mathrm{e}$ ), in which the transposon appear to be inserted in the same chromosomal fragment.

\section{Discussion}

Strains of $\mathrm{Gm}^{\mathrm{r}} \mathrm{Tm}^{\mathrm{r}} \mathrm{Km}^{\mathrm{r}} S$. aureus were first isolated from hospital patients in Melbourne (Perceval et al., 1976) and Sydney (Rountree, 1978) during the mid 1970s and, within 5 years, such organisms had reached epidemic proportions in many institutions (Pavillard et al., 1982). The evidence presented in this and previous work (Lyon et al., 1983, 1984a; Gillespie et al., 1984, 1985) indicates that the gene(s) for $\mathrm{Gm}^{\mathrm{r}} \mathrm{Tm}^{\mathrm{r}} \mathrm{Km}^{\mathrm{r}}$ was (were) located exclusively on the chromosome in the earlier strains, whereas the majority of the later strains exhibited a plasmid-borne determinant. The demonstration that sequences specific to the $4 \cdot 7-\mathrm{kb}$ transposon Tn4001 are associated with both plasmid and chromosomal $\mathrm{Gm}^{\mathrm{r}} \mathrm{Tm}^{\mathrm{r}} \mathrm{Km}^{\mathrm{r}}$ suggests a mechanism whereby this situation could have arisen.

Analysis of $\mathrm{Gm}^{\mathrm{r}} \mathrm{Tm}^{\mathrm{r}} \mathrm{Km}^{\mathrm{r}}$ strains isolated in 1976 revealed that, like strain SK1774, these organisms possessed a chromosomal insertion some $1.3 \mathrm{~kb}$ larger than $\operatorname{Tn} 4001$, whereas subsequent isolates carried a smaller insert consistent with the presence of Tn4001. It is proposed that this change in size of the insert was responsible for producing a $\mathrm{Gm}^{\mathrm{r}} \mathrm{Tm}^{\mathrm{r}} \mathrm{Km}^{\mathrm{r}}$ element which is capable of transposing to diverse chromosomal sites and eventually to a plasmid vector, on which its rapid dissemination was assured. Although the nature of the additional 1.3-kb segment of DNA is uncertain, it does not appear to be equivalent to the $1 \cdot 35-\mathrm{kb}$ inverted repeat of $\mathrm{Tn} 4001$, which can act independently as an insertion sequence (B. Lyon, M. Gillespie and R. Skurray, unpublished observation). Furthermore, it is unlikely that the additional $1.3 \mathrm{~kb}$ of DNA possessed by $\mathrm{Gm}^{\mathrm{r}}$ strains isolated in 1976

\section{REFERENCES}

Archer G L, Coughter J P, Johnston J L 1986 Plasmid-encoded trimethoprim resistance in staphylococci. Antimicrobial Agents and Chemotherapy $29: 733-740$.

Coleman D C et al. 1985 Susceptibility to antimicrobial agents and analysis of plasmids in gentamicin- and methicillin- was responsible for the high-level aminoglycoside resistance displayed by these strains (Gillespie et al., 1984) because strain SK1774, which also possessed this extra DNA, displayed low-level $\mathrm{Gm}^{\mathrm{r}}$.

As well as implying a low degree of insertional specificity, the diversity of chromosomal sites occupied by $\mathrm{Tn} 4001$ in clinical isolates of $\mathrm{Gm}^{\mathrm{r}}$ $\mathrm{Tm}^{\mathrm{r}} \mathrm{Km}^{\mathrm{r}} S$. aureus suggests that this transposon is highly mobile in vivo. It is surprising, therefore, that Tn4001 has probably only transposed to a plasmid in vivo on two occasions, once on to a heavy-metalresistance plasmid to produce pSK23 (Gillespie and Skurray, 1986), and once on to a member of the pSK 1 family. The latter is suggested by the finding that $\mathrm{Tn} 4001$ is inserted at an identical site in all nine $\mathrm{Gm}^{\mathrm{r}} \mathrm{Tm}^{\mathrm{r}} \mathrm{Km}^{\mathrm{r}}$ plasmids, hence we conclude that any structural differences between these plasmids must have evolved after this event. With respect to its cellular distribution, Tn 4001 is unlike other transposons detected in clinical isolates of $S$. aureus, such as Tn554 and Tn4002, which display preference for a single site and orientation of insertion into the chromosome (Murphy et al., 1985; Gillespie and Skurray, 1986; M. Gillespie, B. Lyon and R. Skurray, unpublished observation). It is most likely that Tn 4001 inserted into a plasmid such as pSK 7 from a chromosomal site and, indeed, every strain in which pSK 7 has been detected also harbours a chromosomal $\mathrm{Gm}^{\mathrm{r}} \mathrm{Tm}^{\mathrm{r}} \mathrm{Km}^{\mathrm{r}}$ determinant (e.g., SK 460). This transpositional event would have produced a plasmid equivalent to $\mathrm{pSK} 1$, the most common member of the family and a plasmid so evolutionally successful that it was found in $45 \%$ of multiresistant $S$. aureus strains isolated from Australian hospitals in the early 1980s (Lyon et al., 1983, 1984a) and has also been detected elsewhere (Townsend et al., 1984a). It will be interesting to follow the epidemiology of $\mathrm{Gm}^{\mathrm{r}} \mathrm{Tm}^{\mathrm{r}} \mathrm{Km}^{\mathrm{r}}$ in the future to determine whether Tn4001 dispenses with its plasmid vehicle and once again, like so many other staphylococcal resistance determinants (e.g., penicillin and tetracycline), becomes a stable component of the chromosome.

This work was supported by a Project Grant from the National Health and Medical Research Council (Australia).

resistant Staphylococcus aureus from Dublin hospitals. Journal of Medical Microbiology 20: 157-167.

El Solh N, Fouace J M, Pillet J, Chabbert Y A 1981 Plasmid DNA content of multiresistant Staphylococcus aureus strains. Annales de Microbiologie (Institut Pasteur) 132B : $131-156$

El Solh N, Moreau N, Ehrlich S D 1986 Molecular cloning and 
analysis of Staphylococcus aureus chromosomal aminoglycoside resistance genes. Plasmid 15: 104-118.

Gillespie M T, Skurray R A 1986 Plasmids in multiresistant Staphylococcus aureus. Microbiological Sciences 3:53-58.

Gillespie M T, May J W, Skurray R A 1984 Antibiotic susceptibilities and plasmid profiles of nosocomial methicillin-resistant Staphylococcus aureus: a retrospective study. Journal of Medical Microbiology 17:295-310.

Gillespie M T, May J W, Skurray R A 1985 Antibiotic resistance in Staphylococcus aureus isolated at an Australian hospital between 1946 and 1981. Journal of Medical Microbiology 19: 137-147.

Gillespie M T, May J W, Skurray R A 1986 Detection of an integrated tetracycline resistance plasmid in the chromosome of methicillin-resistant Staphylococcus aureus. Journal of General Microbiology 132: 1723-1728.

Goering R V, Teeman B A, Ruff E A 1985 Comparative physical and genetic maps of conjugal plasmids mediating aminoglycoside resistance in Staphylococcus aureus strains in the United States. In: Jeljaszewicz J (ed) Staphylococci (Zentralblatt für Bakteriologie Mikrobiologie und Hygiene Supplement 14) Gustav Fischer, Stuttgart, pp 625-628.

Gray G S, Huang R T-S, Davies J E 1983 Aminocyclitol resistance in Staphylococcus aureus: presence of plasmids and aminocyclitol-modifying enzymes. Plasmid 9:147-158.

Jaffe H W, Sweeney H M, Weinstein R A, Kabins S A, Nathan C, Cohen S 1982 Structural and phenotypic varieties of gentamicin resistance plasmids in hospital strains of Staphylococcus aureus and coagulase-negative staphylococci. Antimicrobial Agents and Chemotherapy 21 : 773-779.

Kayser F H, Homberger F, Devaud M 1981 Aminocyclitolmodifying enzymes specified by chromosomal genes in Staphylococcus aureus. Antimicrobial Agents and Chemotherapy 19:766-772.

Lyon B R, Gillespie M T, Byrne M E, May J W, Skurray R A 1987 Plasmid-mediated resistance togentamicin in Staphylococcus aureus: the involvement of a transposon. Journal of Medical Microbiology 23:105-114.

Lyon B R, Iuorio J L, May J W, Skurray R A 1984a Molecular epidemiology of multiresistant Staphylococcus aureus in Australian hospitals. Journal of Medical Microbiology 17:79-89.

Lyon B R, May J W, Skurray R A 1983 Analysis of plasmids in nosocomial strains of multiple antibiotic-resistant Staphylococcus aureus. Antimicrobial Agents and Chemotherapy 23:817-826.

Lyon B R, May J W, Skurray R A 1984b Tn4001: a gentamicin and kanamycin resistance transposon in Staphylococcus aureus. Molecular and General Genetics 193:554-556.

Lyon B R, Tennent J M, May J W, Skurray R A 1986 Trimethoprim resistance encoded on a Staphylococcus aureus gentamicin resistance plasmid: cloning and transposon mutagenesis. FEMS Microbiology Letters 33:189-192.

McDonnell R W, Sweeney H M, Cohen S 1983 Conjugational transfer of gentamicin resistance plasmids intra- and interspecifically in Staphylococcus aureus and Staphylococcus epidermidis. Antimicrobial Agents and Chemotherapy 23: 151160.

Murphy E, Huwyler L, Bastos M C F 1985 Transposon Tn554: complete nucleotide sequence and isolation of transposondefective and antibiotic-sensitive mutants. EMBO Journal 4:3357-3365.

Naidoo J, Noble W C, Weissmann A, Dyke K G H 1983 Gentamicin-resistant staphylococci: genetics of an outbreak in a dermatology department. Journal of Hygiene $91: 7-16$.

Pavillard R et al. 1982 Epidemic of hospital-acquired infection due to methicillin-resistant Staphylococcus aureus in major Victorian hospitals. Medical Journal of Australia 1:451454.

Perceval A, McLean A J, Wellington C V 1976 Emergence of gentamicin resistance in Staphylococcus aureus. Medical Journal of Australia 2:74.

Rountree P M 1978 History of staphylococcal infection in Australia. Medical Journal of Australia 2: 543-546.

Townsend D E, Ashdown N, Bradley J M, Pearman J W, Grubb W B 1984a Australian methicillin-resistant Staphylococcus aureus in a London hospital? Medical Journal of Australia $141: 339-340$.

Townsend D E, Ashdown N, Greed L C, Grubb W B 1984b Analysis of plasmids mediating gentamicin resistance in methicillin-resistant Staphylococcus aureus. Journal of Antimicrobial Chemotherapy 13:347-352.

Witte W, Dünnhaupt K 1984 Occurrence of a nonplasmidlocated determinant for gentamicin resistance in strains of Staphylococcus aureus. Journal of Hygiene 93: 1-8. 